\title{
EFFECT OF SPIRULINA MAXIMA ON TNF-A RESPONSE AND GOBLET CELL COUNTS
}

\author{
Ulfah Dian Indrayani, Kamilia Dwi Utami \\ Department of Histology, Faculty of Medicine, \\ Universitas Islam Sultan Agung
}

\begin{abstract}
Background: Cigarette smoke contains toxic and free radical that may cause oxidative damage, inflammation, and an increased risk of degenerative diseases. For prevention, external antioxidants are required. Spirulina maximacontain flavonoid phycosianin and beta carotene. However, few studies have been conducted on the its anti-inflammatory effect. This study aimed to test the effect of spirulina maxima on TNF- $\alpha$ response and Goblet cell counts.

Subjects and Method: This was a randomized controlled trial. A sample of 24 Wister rats was selected for this study, and was randomly assigned to 4 groups: (1) A (2 mL water), (2) B (combination of vitamin C $0.2 \mathrm{mg} / \mathrm{g}$ BW and vitamin $\mathrm{E}$ o,o4IU/gBW), (3) C (Spirulina maxima 250mg/ kg), and (4) D (Spirulina maxima $500 \mathrm{mg} / \mathrm{kg}$ ). The rats were exposed to cigarette smoke 3 times a day for 20 days. On day 21, TNF- $\alpha$ level and number of Goblet cells were evaluated. Differences in means were tested by One Way Anova followed by LSD test, or Kruskal-Wallis followed by Mann-Whitney.

Results: Mean \pm SD of TNF- $\alpha$ of group A, B, C, D, were 774.90 $\pm 2.32,34.08 \pm$ $12.29,232.83 \pm 26.39,353.25 \pm 17.80$, respectively, and it was statistically significant. Number of Goblet cells of group A, B, C, D was 2.4 $\pm 1.4,8.3 \pm 1.5,8.9 \pm 2.3$, $10.4 \pm 4.0$, respectively, and it was statistically significant.

Conclusion: Spirulina $500 \mathrm{mg}$ decreases TNF $\alpha$ levels and increases number of Goblet cells.
\end{abstract}

Keywords: Spirulina maxima, $T N F-\alpha$, Goblet cells

\section{Correspondence:}

Ulfah Dian Indrayani. Department of Histology, Faculty of Medicine, Universitas Islam Sultan Agung, Jl. Raya Kaligawe KM. 4, Semarang, Central Java.

Email: ulfahdian@gmail.com. Mobile: 082227786234 